\title{
THE NEGOTIABILITY OF POSTDATED CHECKS
}

\author{
M. S. BRECKENRIDGE
}

Postdated checks are a chronic affliction in financially anaemic communities and they break out elsewhere often enough to warrant notice. If the results of a rather widespread inquiry are to be believed, they are cordially disliked by bankers, merchants, and tradespeople for the reason chiefly that they are too often drawn against only the flimsiest expectation of funds and they accordingly come back bearing the evidence of their worthlessness on their face.

It is proposed here to consider their status during the embryo stage between the date they are issued and the date they bear and to inquire specifically what is the legal effect of their transfer to a third person during that period.

At the outset, however, it may be well to dispose of certified postdated checks and the responsibility of the certifying bank to the holder, because that issue is sometimes confused with the subject now in hand. As to such a state of facts the law is well enough settled against the holder. Either because it is patently ultra vires on the part of the bank or beyond the apparent authority of the certifying officer, the bank is not liable to him on the premature certification. The latter argument, it will be noticed, might be equally applicable to the issuence of postdated checks by officers of corporations or agents of individuals or by

\footnotetext{
1 Swenson Bros. v. Commercial State Bank, 98 Neb. 702, 154 N. W. 233
} (1915) (president exceeded authority; also said not to be "ordinary banling business") ; Farmers \& Mech. Bank v. Butchers \& Drovers Bank, $16 \mathrm{~N}$. T. 125,129 (1857) (ultra vires); Clarke Nat. Bank v. Bank of Albion, 52 Barb. 592 (N. Y. 1868); Pope v. Bank of Albion, 57 N. Y. 126, 120 (1874) (decided chiefly on another ground); Wilson v. Mid-West State Banl, 193 Iowa $311,314,186$ N. W. $\$ 91,893$ (1922); Luduc v. Banque d'Hochelaga, [1926] Can. Sup. Ct. 76 (only the certification itself was postdated).

In Russell Grader MIfg. Co. v. Farmers Exch. State Bank, 49 N. D. 939, 194 N. W. 387 (1923), a separate letter stating that "the [postdated] check will be paid on that date," was held by the court, under the facts, to bind the derendant bank as an "independent undertaking in the nature of a letter of credit within banking powers." "No evidence was ofiered to show that defendant made this undertaking without consideration or . . . security."

So in the absence of statute with certification of time bill of exchange. Ingersoll v. Kansas State Bank, 109 Kan. 584, 202 Pac. 837 (1921); American Express Co. v. Citizens State Bank, 181 Wis. 172, 194 N. W. 427 (1923). And of a non-commercial instrument in the general form of a check but conditional. Fidelity \& Dep. Co. of Md. v. Nat. Banli of Commerce, 48 Tex. Civ. App. 301, 306, 106 S. W. 782, 784 (1907). Contra: Smith v. Field, 19 Idaho 558, 114 Pac. 668 (1911) (only question involved 
one partner for a partnership. ${ }^{2}$ Unless there was specific authority given, the holder who took such paper would have notice that it was signed in excess of authority just as he would be aware of the same thing in the case of certifications. This is rather a matter of agency than of negotiable instruments, but the inquiry is narrowed nevertheless by this observation to the unusual situation of an agent actually authorized to draw postdated checks or to the common case of an individual drawer of such paper, the one with which we are here concerned.

In order to determine the legal effect of transferring a postdated check, assuming it to be a valid instrument, ${ }^{3}$ it is necessary to consider three distinct matters:

(1) whether a postdated check is negotiable.

(2) whether the date on such a check is notice of the drawer's possible "equities."

(3) whether such a check is regular.

Perhaps it would be more accurate to say that when we have determined what effect should be given to the transfer of a

was whether check certified before its date and now admitted to bo good constituted good deposit under local statutes re appeals); Farmers Nat. Bank v. Ill. Nat. Bank, 146 Ill. App. 136 (1908) (telegraph promise to honor draft on individual held not to be ultra vires where drawee was apparently customer and bank profited from his business); Exchange Bank v. La Banque du Peuple, Mont. L. R. 3 Q. B. 232 (1886), aff'd, 23 Can. L. J. (N. S.) 391, 3 judges dissenting. However, under federal law, banks aro expressly authorized to certify or accept certain kinds of time papor for specified purposes in furtherance of American foreign trade and to provido dollar exchange. FeDERAL REserve Act $\S 13$ as amended by Acts of Sept. 7, 1916 and June 21, 1917, 12 U. S. C. $\S \S 372-373$ (1926). And see Borton v. Central Bank, 10 N. B. 493 (1863). As to a taker after the date on the face of the check, such a certification might be binding despite the fact that it was affixed prematurely and without authority, unless it was dated earlier than the check so as to give notice to any taker that it was premature and unauthorized. Quaere though, whether one must examino the date of certifications. Cf. Merchants \& Planters Bank v. New First Nat. Bank, 116 Ark. 1, 170 S. W. 852 (1914); NegotiabLE INSTRUMENTS LAW $\$ 11$.

2 Forster v. Mackreth, L. R. 2 Ex. 163 (1867) (member of firm of attor. neys having authority to draw checks but not to issue bills; hence no authority to issue postdated checks). And even authority in an agent of $\mathfrak{n}$ corporation to draw regular bills does not carry with it by implication authority to draw postdated bills. New York Iron Mine v. Citizens Bank, 44 Mich. 344, 6 N. W. 823 (1880). But cf. Commonwealth v. Woolis, infra note 59, allowing criminal prosecution against one for issuance of postdated check without funds by general manager of his store.

3 The English cases about to be considered present the issue squarely as one of validity. In other countries it seems to be rather a question of legality: a penalty is prescribed for falsely dating a check. CommercinL LAWs OF THE WORLD, FRANCE 189 (6); TODD, BELGIAN LAW, art. 5, p. 434; HANG, Commercial Code of Japan, art. 536, p. 226. See Comimercial Laws of THE WORLD, SPAIN 152. 
postdated check, we shall then be in a position to answer the question of whether it is negotiable and regular-those attributes being effects rather than causes. But no judge seems ever to have thought of going at it that way, and it is necessary at all events to know what has been decided.

$+$ BRITISH CASES

The British decisions, relied on to a considerable degree in the United States, do not deal with these problems as clearly as might be desired because of the presence in those cases of a non-commercial factor, the Documentary Stamp Tax Acts, which gave rise primarily to the question of validity.

At an early date the Crown imposed a tax on credit instruments which increased proportionately with the time the paper had to run. Englishmen saw the chance to use postdated checks for bills at so many days or months and economize on the stamps. The government retaliated by making postdated checks taxable as bills with a corresponding date for payment," and sought to make this program effective by various statutes declaring unstamped or understamped paper of this sort inadmissible in evidence ${ }^{5}$ or void. ${ }^{\circ}$

\footnotetext{
${ }^{4}$ See Allen v. Keeves, 1 East. 435 (1801). So under the German Ched: Law. 2 Comimercial Lafrs of the Wordd, Geramany 509, \$ 29 . See also Erle, C. J., in Whistler v. Forster, 14 C. B. (N. s.) 248, 255 (1863): "This is an action against the drawer of a bill of exchange, for, though in form a check, the instrument is, for all the purposes of the Stamp Aets, a bill." (Italies ours). That a postdated check is therefore for any other purpose the same thing as a time bill cannot of course be contended. See 1 MIOnse, BANKS \& BANKING (6th ed. 1928) §§ 376-385; Jones, Liability of the Mal:cr of a Check (1892) 6 HARv. L. REv. 138; the discussion of Lord Blacliburn in MIcLean v. Clydesdale Banking Co., 9 App. Cas. 95, 105-108 (1883); that of Cooley, J., in New York Iron Mine v. Citizens Banl;, supra note 2, at $357,6 \mathrm{~N}$. W. at 829; and that of Lord Coleridge, C. J., dissenting in Currie จ. Misa, L. R. 10 Ex. 153, 167-169 (1875). Substantial differences betreen checks and bills persist in the Negotiable Instruments L3w; for example, the "stale check rule" [Nokron, Burs \& Notes (4th ed. 1914) 577-582], and the extent to which tardy presentment discharges the maker- wholly, as to bills (Negotiable INSTRUMENTs LaWF § 70); only as he loses, on checks (NEgotiable INSTrumients LaW \$ 186). And as to the time for presentation of a postdated check, see Rose, J., in Philadelphia Life Ins. Co. v. Hayworth, 296 Fed. 339, 342 (C. C. A. 4th, 1924); cf. Taylor v. Sip, 80 N. J. L. 284 (1863); Mohawk Bank v. Broderick, 10 Wend. 304 (N. Y. 1833). There can be, of course, no justification for calling a checls unreservedly what it is not except with reservations and then reasoning from this tottering premise to general conclusions about checlss. A bill payable "on demand" after a specified future date would bear more perfect resemblance to a postdated check, but even that unusual style of instrument would not be identical.

5 See, e. g., Field v. Woods, 7 A. \& E. 114 (1837), also holding it unneeessary to plead the postdating. But $c f$. as to Canada on this point, Vaughan v. Roberts, 23 N. B. 343, 350 (1883) and citations. See also Ede $\nabla$.
} 
In cases arising under these acts it mattered not who held the paper; the objections to its validity or admissibility were available against either payees or third party holders for value ${ }^{7}$ and by those who had no defence on the merits against anyone. Indeed, and this further illustrates the governmental and noncommercial nature of the question in these cases, the clerk, of the court was required to raise the objection when interested parties did not. ${ }^{8}$ It is therefore apparent that in cases under these statutes, where the paper was held void or was excluded from the record on the ground of violating the revenue acts, the proceedings would be halted short of any question of negotiability. Correspondingly, a decision on whatever grounds that it was not void under those statutes but valid and admissible

Knowles, 2 Y. \& C. C. C. 172 (1843) (headnote-instrument admissiblo in evidence to prove its own invalidity); Watson v. Poulson, 15 Jur. 1111 (1851) (likewise to prove fraud); $c f$. the characteristic language of Lord Ellenborough, C. J., concerning ordinary unstamped check. "I have not legal optics to see its existence." Borrodaile v. Middleton, 2 Camp. 53, 55 (1809).

${ }^{6}$ Whitwell v. Bennett, 3 Bos. \& P. 559 (1803); Serle v. Norton, 0 M. \& W. 309 (1842); see Carrington v. Pell, 3 De G. \& S. 512, 515 (1849). And that a postdated check may, under some statutes, have been illegal beyond cure by stamp, see Key v. Mathias, 3 F. \& F. 279, 281 (1862). This program of Parliament, however, the courts seriously hampered in some cases by testing the sufficiency of the stamp as it appeared when offered in evidence so that time passing before suit begun would gently efface the fault of a check or bill originally postdated. Cf. Upstone v. Marchant, 2 B. \& C. 10 (1823) ; Williams v. Jarrett, 5 B. \& Ald. 32 (1833), criticised but grudgingly followed in Austin v. Bunyard, 6 B. \& S. 687 (1865); also followed in Bull v. O'Sullivan, L. R. 6 Q. B. 209 (1871); and in Gatty v. Fry, 2 Ex. D. 265 (1877). Under such holdings the check could not be said to bo vold whatever the statute declared it. Cf. Watson v. Poulson, supra note 5. But later two judges at nisi prius tried the issue of postdating as a collateral matter, an entirely useless proceeding if the date on the check itself wero to be taken as the test of its admissibility. See Dunsford v. Curlewis, 1 F. \& F: 702 (1859); Key v. Mathias, supra. The variations in statutes and the difference between order and bearer instruments or between admissibility and validity may account for some of these results. See explanatory comment of Blackburn, J., in Austin v. Bunyard, supra at 691. The disadvantages of interrupting a trial by such collateral inquiry were montioned by Cleasby, B., in Gatty v. Fry, supra at 267. It does not seem worth while to examine the seeming inconsistencies further herein. Somo of the statutes, at least, imposed penalties on persons issuing or receiving insufficiently stamped paper. See, e.g., Martin v. Morgan, 3 Moore 635, 638 (1819). But under this type of act the paper was illegal also. Ibid.; Swan v. Bank of Scotland, 10 Bligh (N. S.) 627 (1836). Where depositor "overdraws" account by such void instruments to the knowledge of the bank:, the latter cannot recover from sureties responsible for overdrafts.

7. See Serle v. Norton, supra note.6. In some of the cases it was not oven thought of enough moment to point out whether the plaintiff was the payco or an indorsee, holder for value. See, e.g., Allen v. Keeves, supra note 4.

${ }^{8}$ Oliver v. Mortimer, 2 F. \& F. 127 (1860); Austin v. Bunyard, supra note 6 , at 688 . 
would have not the slightest bearing on the question of its negotiability or regularity while postdated. Moreover, unless in addition the drawer raised or attempted to raise defenses on the merits, there would be nothing in the case to invite consideration of our problem. ${ }^{9}$ Despite that fact, however, there was and continues to be occasional confusion of the two ideas in the language of the courts. ${ }^{10}$ And furthermore, even though the judicial softening of the rigor of this legislation in favor of those who took at a later date without being aware of the postdating may have served to create a class of innocent purchasers in whose hands the paper was valid and available, ${ }^{11}$ that class was in no sense the class with which this article has to deal, $i . e$., those who take for value before the expressed issuing date of the paper

${ }^{9}$ So in Upstone v. Marchant (indorsee against acceptor of postdated bill); Williams v. Jarrett; Austin v. Bunyard; Key v. Mathias; Bull v. O'Sullivan; Gatty v. Fry, all supra note 6; Carpenter v. Strect, 6 T. I. R. 110 (1890) (all actions against the drawer by indorsees for value but with knowledge of the postdating). If the drawers in fact had any meritorious defense in these cases, it would in all probability have been asserted, for able counsel such as those who appeared for the defendants must certainly have seen the point. To assume then that they knowingly omitted to present such a defense would require the further assumption either that the law was considered too well established against them to warrant raising the issue, which is certainly doubtful, or that British business understanding in the use of postdated checks was uniformly and unquestionably in favor of their negotiability from the moment of issue. Whether this was or is so the present writer does not know, but the fact that the question has been since frequently litigated seems to him some evidence that at least it was not. Some of the above cases may be disposed of on another ground, i.e., that the paper was taken by the plaintiff for value on or after its date, at which time it appeared regular and negotiable in all respects. Williams v. Jarrett, Austin v. Bunyard, both supra note 6. So also, London \& Cty. Banking Co. v. Groome, 8 Q. B. D. 288 (1881); Dunsford v. Curlewie, wurro note 6; Ex parte Richdale, 19 Ch. D. 409 (1881) (holder's rights were not litigated). Whistler $v$. Forster, supra note 4 , going off on the ground that the paper being taken by the plaintiff without indorsement was talien subject to the drawer's defenses, gave no occasion to consider or decide whether it might not likewise have been taken subject to defenses because received postdated, though there can be no doubt but that the court did not so think: of it.

10 Kay, L. J., in Royal Bank v. Tottenham, 64 L. J. 99, 101 (1894) : "But the Bills of Exchange Act expressly says that a bill is not invalid by reason only that it is postdated. If it was not an invalid cheque, it was proper to negotiate it before its date and to deal with it as valid." This exact language is not found in the Law Reports, [1894] 2 Q. B. 715. In Carpenter v. Street, supra note 9 , it is said, "The defense set up was that when Carpenter took the cheque it was not 'regular on the face of it' and was not legally valid."

11 This was the actual result of the decision in Austin v. Bunyard, supra note 6 , and particularly the view of Blackburn, J., ibid. 696) although the majority of the court, feeling bound by certain precedent, did not limit their decision to permitting an innocent taker to sue. $C f$. remarli of Cleasby, B., in Gatty v. Fry, supra note 6, at 266, and decision in that case. 
and who then know from the face of the instrument itself that it is postdated. It would therefore be profitless to pursue the matter further.

This summary will be found on analysis to dispose of most of the British cases in which questions were raised concerning postdated checks. Space forbids detailed consideration here of any but a few of the others.

In Hitchcock v. Edwards, ${ }^{12}$ a check was made by the defendant and delivered to the payee on September 5th, dated September 8th and transferred for value to the plaintiff on September 6th. It was contended by the drawee-defendant that the check was not complete and regular on its face when transferred to the payee in that it was then postdated and bore only a penny stamp, that the plaintiff therefore was not a holder in due course, and that the defendants might set up against him certain defenses. Cave, J., held for the plaintiff, and his oral opinion seems squarely to have decided (1) that the check was not invalid provided it appeared properly stamped when offered in evidence, and (2) that it was regular and negotiable before its date. As authority for both of these propositions the court depended entirely on the case of Gatty v. Fry. "That is a decision that is binding on me sitting as a judge of the first instance. . . . Before the defendants can succeed they must get rid of Gatty v. Fry."

But Gatty v. Fry, one of the cases cited above, ${ }^{13}$ decided nothing about negotiability or commercial regularity and the defendant failed to show in that case that he had any defense on the merits which would make it material whether the plaintiff took by negotiation or by mere assignment. The only issue there was one of validity. As authority on that proposition it is sufficient; for more than that it is not, and Hitchcock v. Edwards loses in turn some of its persuasiveness as authority on commercial law for being bottomed on that non-commercial precedent.

But it may be urged that the matter of irregularity was argued and considered and the pertinent section of the Bills of Exchange Act ${ }^{14}$ was pressed upon the judge's attention. True, but there

1260 L. T. R. 636 (1889); approved in Royal Bank v. Tottenham, supra note 10.

13 Supra notes 6 and 9.

14 BILIS of Exchange ACT § 29: "A holder in due course is a holder who has taken a bill complete and regular on the face of it. . . NEGOTIABLE INSTRUMENTS LAW § 52: "A holder in due course is a holdor who has taken the instrument under the following conditions: 1. That it is complete and regular on its face." The Negotiable Instruments Law scctions will be later considered in detail but this section being but a codification of the law merchant [Hunter v. Bacon, 127 App. IDiv. 572, 111 N. Y. Supp. 820 (1st Dep't 1908)] adds no complication to this or the other British decisions under it. 
is apparent in the argument an unmistakable interweaving and confusion of this section of codified commercial law with the stamp acts-revenue law. The irregularity of the check is sought to be made out by a combination of these two; it was irregular when the plaintiff took it, not because it was then postdated, the commercial reason if there is one, but because, being postdated, it then bore an insufficient stamp to the knowledge of the taker. What the court failed to consider and what was never sharply and clearly presented to it for consideration was the question of irregularity under the law merchant and the Bills of Exchange Act alone, in which case matters of commercial convenience and mercantile custom would doubtless have received attention. ${ }^{15}$

A much earlier case, Pasmore v. North, ${ }^{16}$ concerned a postdated bill and therefore involved elements not present in check cases, notably the fact that a bill is a time or credit instrument rather than a cash order; but it is the most extensively reasoned case on the problem of postdating commercial paper and therefore demands review. The defendant on May 4, 1810 drew a bill on a London firm, dating it Mray 11, but immediately delivering it to the payee, one Totty. On the next day, May 5, Totty endorsed it to the plaintiff for value and later that day was killed by a fall from his horse. Hearing of this, the defendant stopped payment on the bill and resisted its collection in this action. It may be taken as a fact, although it is not entirely clear, that the consideration for the bill failed in part; at least the defendant owed Totty, the payee, less than the amount of it when accounts were balanced. The question as stated by the plaintiff's counsel was "whether the bill having been drawn and indorsed to the plaintiff before the day that it bears date, and the payee having died before that day, it was a negotiable instrument at the time, within the custom of merchants, so that the payee could convey a title to it by his indorsement to the plaintiff." He argued that the date was not material except to fix the time of payment, which here it sufficiently did. Littledale for the defendant contended, however, that "The bill never had any operation by the custom of merchants, which does not apply to an instrument carrying a false appearance and deception upon the face of it. It was only meant to be taken as issued at the time of the date, and until that day it was not a negotiable instrument, however it might bind the drawer to answer for the

\footnotetext{
15 It seems likely also that there was no valid defense on the merits in Hitcheock v. Edwards, supra note 12. The one presented was that defendant drawer had been garnished by creditors of the payce before the date of the check. There being no duty to stop payment on the check for the benefit of these creditors [Ex parte Richdale, supra note 9], it may be that there is no privilege of doing so as against a purchaser for value.

1613 East 517 (1811).
} 
amount to the payee or his executors." ${ }^{17}$ (This last contention smacks more of the common-law problem about the assignability of choses in action, the question of whether the owner can give as much as he has, or anything at all, than of negotiability, the question of whether he can give more than he has, launder his dirty paper and free it of defenses.)

It may be, therefore, that the question of negotiability was not as directly raised and settled in Pasmore $v$. North as at first appears, but it is not proposed to side-step the case in this fashion but to accept it as deciding exactly what it has been considered to decide and to examine the sufficiency of the reasons for the decision.

There can, in the first place, be no criticism of Lord Ellenborough's disposition of the fraud argument. So long as the paper circulates postdated, that fact is apparent; during that time it could be at most an evident fraud on the revenue. When once the day scheduled for its debut arrives, it may be deceptive in suggesting that the day specified was really the day of its "coming out," but the deception is harmless, for takers thereafter are, if anything, benefited by their ignorance. ${ }^{18}$ And there can be no doubt either of the correctness of Lord Ellenborough's position in demanding pointedly of counsel: "Does he mean to say that it was in abeyance in the intermediate time between the issuing of it and the date?" From the moment of its delivery to Totty the bill had some legal significance. But neither of these things, of course, decides that the instrument is or ought to be negotiable before its date.

17 The explanation of this argument may be as follows:

(1) An ordinary chose in action was not assignable at common-law.

(2) Certain special choses in action, commercial instruments, woro mado assignable by the law merchant; in fact they were made more than assignable-negotiable.

(3) The term "negotiable" was undoubtedly used originally to indicate assignable in such a manner as to permit suit by the assigneo in his own name. See language of the statute of $3 \& 4$ ANN. c. 9, $\$ 1$ (1704); Shaw v. N. Penn. R. R, 101 U. S 557 (1879). It is still so used, but it may bo employed in a more exact and discriminating sense to mean assignablo in such a manner as to cut off personal defenses. It is so used by the writer. In the case of Pasmore v. North, supra note 16, it is evident that Littledalo, from the emphasis he placed on the death of the indorser, was thinking of strict assignability when he spoke of the instrument as being non-nogotiable, though he gave a reason which was equally applicable to either uso of the term, i.e., that this was not at its issuing date such an instrument as the law merchant was concerned with. In so far as the case may depend upon the legal assignability of the instrument, its possible operation as a power of attorney coupled with an interest, and the right of tho assignee to sue in the name of the deceased payee or of his executor, the subject is beyond the scope of this paper. See Cook, The Alienability of Choses in Action (1917) 30 HaRv. L. REv. 449.

${ }^{18}$ See suprä note 11. 
The remaining remark of the learned Lord Chief Justice is the one which would lend the most support to that contention: "A bill without any date would still be a good bill: then why is not this as good?" If by this is meant good as a time bill and operative from delivery as such, hence negotiable in the correct sense of that term, ${ }^{10}$ nothing could be more faulty by way of analogy. There is a clear and important difference between failing to date a bill and postdating it, whether the failure to date is careless or intentional. In the case of carelessly failing to date, the very lack of thought on the subject is most persuasive evidence of the drawer's indifference and willingness that the bill be immediately negotiable; if he cared he would have thought; ${ }^{20}$ and in addition, there is no reason why business should be held in check for the protection of heedless persons. In the case of deliberately omitting the date, the author of the bill takes the ordinary principal's risk with his eyes open and cannot complain of results.

On the other hand, consider the case of postdating. It is an affirmative act, ordinarily represents thought and is done for a purpose. ${ }^{21}$ The bill is placed in the hands of the payee with evidence of that fact upon its face. To say, therefore, as did LeBlanc, J., in Pasmore v. North, "that the very party who now set up the defense that this was not a negotiable instrument, was the person who issued it into the world as such," 22 is to beg the question. He sent it forth differing from the ordinary commercial instrument in a noteworthy particular, subject to the chance that the courts might declare it regular and negotiable whenever a case arose requiring a decision on that point. But why create new rights in unusual paper?-a thing justifiable only in furtherance of the turnover of such paper as is in due course.

19 In view of the form which the later English codification of the lav merchant took (see infra note 42), there is some justification for believing that negotiability was not meant by this rhetorical inquiry. If that is true, Lord Ellenborough's opinion decided the case vithout meeting the issue of negotiability by a single valid reason.

${ }^{20}$ This, of course, is not intended as a subjective test of the negotiability of a particular bill.

21 It is not overlooked that there are cases of careless misdating too, but no reason is perceived why they should influence the rule which may be adopted for postdated instruments. The court properly disregarded the obvious fact that there had been an inadvertent misdating in Bochm v. Sterling, 7 Durnf. \& E. 423 (1797), where it was evident that the intent was to postdate several months, but by error in the year written the bill was actually antedated.

${ }^{22}$ Supra note 16, at 522. There is some evidence in the case of the drawer's expecting, perhaps intending, that Totty should "pay it the next day at Doncaster," that is, deposit or transfer it then. In the absence of an estoppel, however, his intention or knowledge of it should not afiect the result. 
In spite, nevertheless, of the seemingly misplaced emphasis on the death of the payee, the confusing presence of the stamp tax question regarding validity, and the not too satisfactory reasons given by the court for its decision, Pasmore $v$. North remains the squarest and strongest of the English cases on the general subject of postdated commercial paper. As later to be observed, it does not necessarily cover the case of postdated checks.

In Robinson $v$. Benkel, ${ }^{23}$ the plaintiff, a broker, bought from a bankrupt gambler named Harley certain postdated checks of the defendant given in payment of wagers. These facts being shown, the plaintiff was obligated to prove himself a holder in due course. Horridge, J., having disposed of the stamp issue which had been raised, then dealt with the question of notice in the following interesting language: "The difficulty of talking postdated cheques from a man he knew to have been a bankrupt was gotten rid of by the fact that during the last few months he had discounted other cheques for him and they had always been met."

Here is an intimation clearly enough that if past transactions had not served to Iull the plaintiff into confidence, he might have been chargeable with notice of some defect because he took postdated checks from a known bankrupt. One wonders where the emphasis is laid, on the character of the check or on the character of the transferor. If the former, the learned judge leaned to the view that a postdated check, while valid and negotiable, is not regular, or at least that it is notice on its face of possible defenses, though such leanings are certainly not in harmony with the orthodox English views on the subject. If the latter, it suggests a reversion to the discredited rule of Gill $v$. Cubit ${ }^{24}$-an unlikely move at this date. The possible irregulnrity of the paper was not considered, but the result is opposed to such a view, for it is not perceived how the drawee's payment in due course after their date of some checks originally postdated could protect one in the premature purchase of other like instruments. That fact might be material, however, if the question was one of notice or simply a fact question of the buyer's good faith; and perhaps this last is all that the language means anyway.

But the most interesting of the British cases are three from Australasia, wherein the arguments struck directly at the effectiveness of postdating for any purpose. In Hinchcliffe v. Ballarat Banking Company, ${ }^{25}$ a lower court of Victoria held that to postdate a check is to mislead the drawee bank, and the bank, there-

2329 T. L. R. 475 (1913).

243 B. \& C. 466 (1824). Cf. Goodman v. Simonds, 20 How. 343 (U. S. 1857).

251 Vict. L. R. 229 (1870). 
fore, should not be the loser if it pays such a check before the date it bears and in consequence dishonors a subsequent check because of the depleted state of the drawer's account. But the Supreme Court reversed this decision. It held that the bank must observe the date, because otherwise it would be allowed to pay a bill before it was due, since a postdated check is a bill. The bank was negligent and must respond in damages.

But when a similar question was presented to a Queensland court some twenty-five years later, a contrary result was reached in two opinions which bristle with novel ideas on the subject.ac Conceding that prior to the codification of the law merchant the bank could not be justified in the practice of prepaying postdated instruments, the opinion of Griffith, C. J., lays weight on Section 14 of the Bills of Exchange Act, 1884 (which provides that unless the contrary is proved, the date appearing on a negotiable instrument will be considered the true date) ${ }^{27}$ as support for the view that the true date of the check in question could be shown to be the date when it was delivered to the payee. The check then being an instrument payable on demand after its true date was payable immediately on issuance without regard to the date written upon it. It is difficult to accept this reasoning and conclusion, for the section making the witten date prima facie the true issuing date was apparently addressed to the burden of proof in the case of an instrument whose date had been altered, ${ }^{23}$ and the reasoning was not altogether supported by the other judges, for one of them in a concurring opinion presented grounds of his own for reaching the result.."

${ }_{26}$ Magill v. Bank of N. Queensland, 6 Queens. L. J. 262 (1895), commented on favorably in (1920) 64 SoL. J. 597, and in fact announcing the doctrine previously suggested by that periodical, Post-dated Cheques (1883) 27 SoL. J. 194, although the more recent article seems not to have been aware of it. See also arguments of counsel in Forster v. Mackreth, L. $\mathbb{R}$. $2 \mathrm{Ex} .163,165$ (1867).

27 BILLS OF EXchaNGE ACT (Eng. 1882) § 13 (1) ; NEGOTLABLE INSTRUMENTS LAW § 11: "Where the instrument or an acceptance or any indorsement thereon is dated, such date is deemed prima facie to be the true date of the making, drawing, acceptance, or indorsement as the case may be"

${ }^{28}$ See National City Bank v. Shelton Electric Co., 96 Wash. 74, 164 Pac. 933 (1917).

29 He refused to decide whether the instrument was a bill payable on demand from the moment of issue or on demand after its date. If the former, the bank's right to pay was clear, and if the latter, the bank was entitled to accept the check before its date and thereafter to dishonor other checks, and also the bank might pay it before its date "from its own funds" and hence vithout the privilege of charging it against the depositor at that time. It is believed that this latter reasoning will not bear the light of analysis. First, as to acceptance, even if contrary to American practice the bank can lawfully bind itself by accepting a time instrument vithout debiting the depositor's account to cover the acceptance, no reason appears why it should then be permitted to dishonor other earlier maturing 
In 1901 this case was disapproved by the New Zealand Court of Appeal, where exactly the same problem was raised. ${ }^{30}$ One of the opinions warrants examination. Williams, J., considered that if the Queensland reasoning were adopted, a holder could sue on the postdated instrument before its date, a result to which he was unwilling to yield assent. But in this particular he overlooked the most striking feature of the Queensland decision. Whether the bank may justifiably pay without regard to the date is one problem. Whether a holder can demand payment and treat the refusal as a dishonor is another. Whether he is a holder in due course and free from "equities" is still another. Logic does not demand that these problems be resolved together; neither necessarily does business policy. If postdating affects the decision on any of them, there are still postdated checks to be reckoned with. Griffith, C. J., in the discredited Queensland case, saw this distinction, for, to counsel's contention that the decision does away with postdated checks, he made ready answer no, because one who takes the check has notice that the person having it in possession may have no right to it ("It is a document which is apparently not in circulation as a negotiable instrument") and so takes that risk, but if it later turns out that the person had a right to it, the risk proves to be nothing. ${ }^{32}$ The reasoning of the learned judge is exactly and strikingly applicable to non-negotiable paper where a defect of title is concerned.

Here then, in a case which has been misunderstood as practically abolishing postdated checks, is a dictum according more effectiveness to the postdating than is usually granted and suggesting much the same policy on the particular point as that presented by the present article for consideration.

It is not intended here to approve the decision in the Queensland case. Since due diligence by a drawee requires observance of the date of a draft along with all other material matters on its face, the bank should be required to refuse payment on postdated instruments until their date arrives. ${ }^{32}$ And such it is understood is the practice. But the Queensland decision is far from announcing a curious and indefensible rule as a first read-

checks on the still undepleted account. Second, if the bank "pays" the instrument "from its own funds," i.e., without charging the customer's account, such a transaction is a purchase, not payment, and there still appears no reason why regular checks presented prior to the date of the postdated check should not be honored.

30 Pollack v. Bank of New Zealand, 20 N. Z. L. R. 174 (1901).

31 Magill v. Bank of $N$. Queensland, supra note 26 , at 264 .

32 "If a banker pays a check before it is due, he is not protected." Parke, B., on argument in Morley v. Culverwell, 7 M. \& W. 174 (1840). Accord: Commercial Bank of Scotland v. Henderson, 13 Scot. L. Rev. \& Sher. Ct. Rep. 136 (1897) (depositor who gave notice to stop payment before the dato of the check allowed to recover the amount thereof from the drawee bank 
ing might suggest. It is novel and perhaps not advisable; that is all. The best reason which can be given for the rule seems to be the one which grounded the lower Victorian court in its judgment, later reversed, in the Hinchcliffe Case-that the depositor misleads the bank, that he owes a duty not to so draw checks as to increase the likelihood of slips in the volame of business done. And a junior bank officer in an American city emphatically expressed a like opinion when asked concerning the payment of such items, without ever having heard of a decision on the question. The paying teller and bookheeper would, of course, be relieved of one responsibility by such a state of the law, and the work of the bank be speeded up in some measure, but a banker's view, though honestly entertained, is prejudiced by a lively appreciation of his own problems, and a solution must be arrived at only when his opinion is weighed with those of others whose interests are at stake. One effect of a decision like that in the Queensland case would undoubtedly be to discourage the drawing of postdated checks-2 laudable accomplishment in itself but entailing sacrifice of some cherished conveniences from that form of instrument. In the light of the cases considered above and others, both British and colonial, which are summarized in a note, ${ }^{33}$ it would seem definitely established in the British Empire that a postdated check is a negotiable and regular commercial instrument from the moment of its issue, and the future date upon it is not considered notice to an indorsee of the drawer's possible defenses against the payee.

CASES IN THE UNITED STATES

\section{(1) Those Prior to the Negotiable Instruments Law}

The early American cases, being free from foreign stamp entanglements, did not usually go off on the matter of validity,

which had already paid it and charged his account). Here there was no holder in due course unless the drawee were such; cf. The Stag Co. v. Union Bank of Chicago, 201 Ill. App. 510 (1916). In Godin v. Bank of the Commonwealth, 6 Duer 76 (N. Y. Super. Ct. 1856), a like recovery was permitted but in favor of one to whom the bank balance had been assigned before the date of the postdated checks in question but after their "payment" by the drawee defendant. See Grawford v. West Side Bank, 17 Jon. \& S. 68,72 (N. Y. Super. Ct. 1SS3), containing, however, a dictum that the drawee could then recover of the drawer. It has been held in Germany that a bank which pays a postdated check before its date must bear the risk of a subsequent stop payment order and must refund to the holder whose messenger collected the check and absconded, the holder having talien an assignment from the drawer. Conmerclal Litrs of tue Worsd, GenMIAVY, 489 .

33 Currie v. Misa, supra note 4; Watson v: Poulson, stgra note 5. In neither of these cases was the suit on the postdated instrument. One was on an ordinary check given in payment of a postdated bill, or in response 
and accordingly they presented more squarely the simple question of a holder's rights in the face of a maker's personal defenses. Occasionally, it is true, the court declared the postdated instrument to be valid and let the case go at that, ${ }^{34}$ while at other times the check was simply said to be a negotiable instrument, or the taker a holder in due course, or the maker precluded from setting

to a postdated message or memorandum, as the court seems to have regarded it. The other was an action in tort for the fraud of the drawer in issuing a postdated check on which he had stopped payment because of failure of consideration before the purchaser of the check for value way able to get it cashed. Parke, B., regarded the stopping of paymont as "justified," which probably did not mean that the drawer could have set up the defense had he been sued on the check. Cf. Royal Bank of Scotland v. Tottenham, supra note 10 (suit by purchaser for value before its date of check drawn by defendant; no evidence of defenses; claim that plaintiffs should not recover because they took it insufficiently stamped; held, valid and admissible and that plaintiff might recover); Wood v. Stephenson, 16 U. C. Q. B. 419 (1858) (suit by purchaser of check for value beforo dute; defense of failure of consideration; held, valid and that plaintiff might recover); followed in Union Bank v. Tattersall, 52 D. L. R. 409, 411 (1020); Hutley v. Peacock, 30 T. L. R. 42 (1913) (cheek of minor drawn and delivered before, but dated after, becoming of age; treated as a bill; defense of infancy sustained; and therefore nothing decided on question of negotiability or regularity). In Stirling v. John, [1923].1 K. B. 557 postdated checks were deposited with a money lender for the purpose of paying up installments of the drawer's debt as they came due; no question of whether the checks were negotiable was involved, but solely whether they were "securities" for the payment of money within the meaning of certain statutes regulating the business of money lending. Younger, L. J., called them "negotiable instruments" but obviously meant simply that they were commercial paper in a general sense. $C f$. Russell v. Hellaby, [1922] N. Z. L. R. 186 (suit by payee, hence no question of negotiation; check postdated to enable drawer to try out car sold to him before final payment). Other decisions from the far stretches of the Empire for the most part contribute little. Most of them turned on the revenue laws, and whatever they may add by way of cumulative weight to the English view is discounted by the fact that the colonial courts were but following the decisions at Westminster, or attempting to follow them. In the following cases no defense on the merits was made out and the decision hinged on the validity or invalidity of the bill otherwise, as, e.g., under the stamp acts: Ramen Chetty v. Mahomed Ghouse, Indian I. R. 16 Calc. 432 (1889) (held admissible in evidence, following English test of appearance at trial); Chartered Mech. Bank v. Silva \& Co., [1866] Rama Nathan's Ceyl. R. 199 (no right of action on insufficiently stamped postdated check by one who took with knowledga of fact) ; Krishnappa Chetty v. Carpen Chetty, 15 Ceyl. New L. R. 243 (1912) (contra, on ground of change in statute); Alexander v. Sheth, 6 So. Afr. 162 (1899); Van Graan v. Buytendag, [1907] Transvaal L. R. 550 (Sup. Ct.) (promissory note; urged that plaintiff was not a holdor in due course because the instrument was not complete and regular when ho took it; but defendant having no defenses on the merits, the declaration of the court that it was complete and regular as an instrument-independent of stamps-is of less force than otherwise it vould be).

The case of Jochelsohn, Yamey \& Co. v. Mahomed, [1916] So. Afr. L. R. Cape Prov. Div. 233, decided only that the mistaken taking of a postdated 
up defenses, and all debate on those questions foreclosed by the judicial pronouncement. 35

But when any reasoning at all was indulged in, it was usually directed to the question of whether the presence on an instrument, in general form negotiable, of a date yet in the future is notice of equities existing between the original parties, whether it is a suspicious circumstance on the paper. Thus, in the earliest American case on the general subject of postdated instruments, suit being upon a promissory note, the trial judge "charged the jury that the negotiation of the note, before the day when it bore date, was a strong circumstance of suspicion, sufficient to put the plaintiff upon inquiry, and that he therefore took it subject to any defense which might have been made had the suit been brought by the original payees"; while on appeal a contrary opinion was expressed by Sutherland, J., as follows: "There is no legal objection either to antedating or postdating a note, and I am not prepared to say that either is, in itself, and disconnected from other circumstances, a legal ground of suspicion, so as to put the indorsee upon inquiry, and subject him to all the equities existing between the original parties." 35 This decision was followed and substantially the same language used in a later case where the instrument was a check instead of a note. ${ }^{37}$

To the same effect, though phrased in terms of notice rather than of suspicious circumstances, is a dictum of the Supreme Court of Indiana in another case where the maker had requested delay in collecting an ordinary check, not postdated, and the holder knew of such request. "We cannot see that the transaction carries a more distinct warning of fraud to a possible

check by a creditor who thinks it immediately payable does not bar his suit on the original debt when payment of the check is refused.

Bishendas Mionghirmal v. Akbar Khan, 8 E. Afr. L. R. 156 (1920) deals with a bill of sale (mortgage) of cattle as security for a loan of Rs 5000 . A statute required every bill of sale to set forth truly the consideration, and the court treated a statement that the Rs 5000 were "now paid" as false when some part of that sum was in postdated checlis. The court seems by this decision to classify the postdated check as a cash instrument operative as payment only as of its future date rather than as a credit instrument so operating when delivered. One wonders whether he rould have held likewise of a time bill intended for immediate discount. See Post-Dated Cheques (1913) 136 Law Trmes 59.

34 Frazier v. Trow's Ptg. \& Bkbdg. Co., 24 Hun 281 (N. Y. 1881).

35 Jacks v. Darrin, $3 \mathrm{Sm} .557$ (N. Y. 1854); Anderson v. Shoup, 17 Ohio St. 125 (1866) semble; Burns v. Kahn \& Furst, 47 Mo. App. 215 (1891) ; Bill v. Stewart, 156 Mass. 508, 31 N. E. 386 (1892); Wilson v. MicEachern, 9 Ga. App. 584, 71 S. E. 946 (1911); see Walker v. Geisse, 4 Whart. 252, 257 (Pa. 1839) (not necessary to a decision of the case but following Pasmore v. North, supra note 16).

${ }^{36}$ Brewster v. MrCardel, 8 Wend. 478 (N. Y. 1832).

37 Ifeyer v. Mode, 14 Hun 155 (N. Y. 1878). 
purchaser than would a postdated check; or a memorandum check. . . . Neither a postdated check nor a memorandum check in themselves are notice of fraud in putting them in circulation sufficient to destroy the bona fides of a purchaser for value." 38

It will be seen, therefore, that in American cases not governed by the Negotiable Instruments Law the courts have touched upon two of the problems presented for consideration herein, i.e., (1) whether a postdated check is negotiable and (2) whether the date constitutes notice of possible defenses, though this latter point was at times discussed as a question of suspicious circumstances. The decisions on these points were reached chiefly in reliance on English precedents and without examination of American business practice. The third of the questions raised at the opening of this paper, i.e., that concerning the irregularity of a postdated check, did not become recognized as a separate issue until after the passage of the Negotiable Instruments Law, whose provisions are now to be examined.

\section{(2) The Negotiable Instruments Law}

This codification of the law merchant did little to clarify the problem of postdated checks.

"A check is a bill of exchange drawn on a bank payable on demand." 39 But far from proving that a postdated check is, when issued, a regular bill of exchange payable at a future time, this language goes only so far as to indicate that a postdated check is not when issued a regular check, perhaps not really a check at all, for nothing could be clearer than that, whatever else it may be, it is not then payable on demand. A bank would violate a duty to its customer by paying it and charging the customer before the date it bore, ${ }^{40}$ and a certification would be equally unauthorized if accompanied by the usual practice of tying up the depositor's account in part to meet the check.41

Nor will much support for the view that a postdated check is a regular and negotiable instrument be found in the other sections of the Negotiable Instruments Law. It may well be conceded that, as provided by Section 6 , the negotiable character

38 Johnson v. Harrison, 177 Ind. 240, 251, 97 N. E. 930, 934 (1912) ; of. dictum in Pope v. Bank of Albion, supra note 1, at 130, to the effect that one who purchased the postdated check in question "might certainly havo been charged with notice of some irregularity, on account of receiving it before the day of its date." But that check had been certified. See also infra note 55.

s9 Negotiable InSTRUMents LAW § 185; so also English and Canadian BILLS OF EXCHANGE ACT $\$ 73$.

to Supra note 32.

11 But of. Smith v. Field, supra note 1. 
would not be affected by the absence of any date, for that is not in issue, there being in fact a date on the paper; its being there is, under another section, a material feature of the check, not subject to alteration ${ }^{43}$ and required to be observed by takers, as is the amount. For the same reason no light is shed on the question by Section 17, which offers rules of construction for undated instruments.44 And a glance at Section 13, also dealing with dating of undated time instruments, is all that is needed to show that it does not fit the case. ${ }^{45}$ So too, Section 1, providing as a condition of negotiability that the instrument must be payable on demand or at a fixed or determinable future time, does not determine the problem, for, while it is conceded that the time is sufficiently fixed by the postdating, nothing is thereby proved as to regularity. And even negotiability is not finally established by meeting one of the conditions for its existence.

It may be further granted, without affecting the issue, that an instrument is not invalid because antedated or postdated 45 for it is not contended in the United States that a postdated check is invalid. ${ }^{13}$ The question is whether during the interim it is either non-negotiable, irregular, or notice of defenses. But while this language of Section 12 fails entirely to prove anything

42 The English and Canadian acts provide only that the bill is not invalid because undated. BranNaN, Negotrable INSTruarents Lay (3d ed. 1920) 26, n. 1; Russell, Buls (2d ed. 1921) 113; Canadian Bils of Exchasige ACr $\$ 27$ (a).

43 Negotiable Instruments Law \$ 125. See Stephens v. Graham 7 S. \& R. 505 (Pa. 1822).

14 NeGOTIABLE INSTRUAIENTS LAT \$ 17: "Where the language of the instrument is ambiguous, or there are omissions therein, the following rules of construction apply: . . 3. Where the instrument is not dated, it will be considered to be dated as of the time it was issued." This, of course, is just what cannot be "considered" when a date appears on the face-even though for some purpose evidence were admitted as to the true date of first handing over or delivery.

45 Ibid. § 13; cf. BILls of Exchange ACT § 12.

${ }^{46}$ Relied on in Mianos v. Eassy, 124 S. C. 154, 117 S. E. 222 (1923). But see the argument of Mullan, J., concurring in Kuflik v. Vaccaro, infra note 49 , that a postdated check is not payable at "a determinable future time" as defined in Negotiable Instruments Law, $\$ 4$, and hence does not qualify as negotiable.

47 Negotiable Instruntents Latp § 12; BuLs of Exchange ACT (Eng.) $\S 13$ [2]; BILLS of Exchange ACT (Can.) § 27 (d).

48 This is all that is decided on the point by American Agricultural Chem. Co. v. Scrimger, 130 Md. 389, 396, 100 Atl. 774, 776 (1917), wherein it was said, "A postdated check is a perfectly legal and proper instrument. ..." It is true, of course, as held in that case, that in the absence of collusion to cheat creditors there is no duty on the part of a drawer of postdated checks to stop payment on them for the benefit of a garnishing creditor of the payee. Ex parte Richdale, supra note 9; Elwell v. Jackson, 1 Cab. \& E. 362 (1884) (likewise as to ordinary check); cf. Wilson v. McEachern, supra note 35; Fulweiler v. Hughes, $17 \mathrm{~Pa} .440$ (1851). 
favorable to the negotiability of postdated instruments, it does, when set side by side with that of Section 6 already mentioned, offer a foothold for an argument that they are not negotiable. The provisions are as follows: Section 6: "The validity and negotiable character of an instrument are not affected by the fact that it is not dated:" Section 12: "The instrument is not invalid for the reason only that it is antedated or postdated provided this is not done for an illegal or fraudulent purpose." (Italics ours).

Out of this group of sections dealing with dates there seems then to be no compelling argument for or against negotiability. As might be expected, therefore, the courts since the Negotiable Instruments Law, in deciding that a postdated check is negotiable, ${ }^{49}$ have found little assistance in the Act, but have depended largely on the earlier decisions already noticed.

As to the matter of notice, the Negotiable Instruments Law has nothing specifically to say about postdated instruments. The general provisions of Section 56 that, to constitute notice of equities, the transferee must have had knowledge thereof or of

49 Symonds v. Riley, 188 Mass. 470, 74 N. E. 926 (1905); Albert v. Hoffman, 64 Misc. 87, 117 N. Y. Supp. 1043 (Sup. Ct. 1909); Kuflik v. Vaccaro, 103 Misc. 239, 170 N. Y. Supp. 13 (Sup. Ct. 1918); Triphonoff v. Sweenoy, 65 Ore. 299, 130 Pac. 979 (1913); State v. Langer, infra note 58; Amer1can Nat. Bank v. Wheeler, 45 Cal. App. 118, 187 Pac. 128 (1919) (check issued before the Negotiable Instruments Law was adopted); Currie-MICGraw Co. v. Friedman, 135 Miss. 701, 100 So. 273 (1924); cf. Jackes-Evans Mfg. Co. v. Goss, 254 S. W. 320 (Tex. Civ. App. 1923). This last caso is one of the most remarkable that has been found and presents a jury vordict in a curiously unfavorable light. The defendant's check having beon drawn and delivered in December, 1920, but dated February 10, 1021, was evidently indorsed before the latter date to the plaintiff company (so that under the view of this article the instrument would be subject to the drawer's defenses). This is exactly what the jury was determined to find; but, having been instructed, it seems, that the check matured on the day of its date and that to be a holder in due course the plaintiff must havo purchased before maturity, it found against the clearest evidence that the plaintiff company "did not get" the check until "after February 10, 1921" and so was not a holder free from equities. The appellate court roversed the judgment on this flagrant misfinding of the facts without oven an allusion to the elementary proposition of law that the check would have been negotiable for some time after its date and that the very facts which tho jury found would make the plaintiff a holder in due course whether he would have been so before its date or not. Under any interpretation of the evidence the plaintiff could not have taken the check more than two or three days after its date and even under the strictest holdings it would havo continued negotiable for a much longer time. NEGOTIABIE INSTRUMENTS LAW §§ 53, 193; Anderson v. Elem, 111 Kan. 713, 208 Pac. 573 (1922) (24 days not an unreasonable time). If the trial court had not certainly misled the jury and the jury as certainly determined, whatever the evidence, to exempt their fellow Texan from the claims of a St. Louis corporation, tho case would have been an excellent one for a judicial consideration of our problem. 
such facts that his action in taking the instrument amounted to bad faith, ${ }^{50}$ has not prevented courts treating matters appearing on the face of the instrument as the equivalent of actual knowledge; ${ }^{\top}$ but the courts in dealing with postdated instruments under this provision have not regarded the date as notice of the drawer's equities under the Negotiable Instruments Law any more than they did before.:

We turn next to the matter of regularity. The Negotiable Instruments Law defines a holder in due course as one who, among other things, has taken an instrument "complete and regular on its face." "53 Since no test of regularity is laid down, it would be a fair enough inference that guidance should here be sought from the commercial world. ${ }^{\text {ss }}$ But counsel and judges who care what merchants think or understand about a question which lawyers have taken unto themselves as one of law are a rarity since the day of Lord Mansfield. No such investigation seems ever to have been made or thought of; indeed, no question of the regularity of postdated instruments seems ever to have been seriously pressed upon the attention of a court.55 Inquiry

${ }^{50}$ NEGOTLABLE INSTRUMENTS LAW $\$ 56:$ "To constitute notice of an infirmity in the instrument or deiect in the title of the percon negotiating the same, the person to whom it is negotiated must have had actual knowledge of the infirmity or defect, or knowledge of such facts that his action in taling the instrument amounted to bad faith." The subjective nature of the test is most forcibly put by Mr. Justice Mrack's remark in Schintz v. American Trust \& Sav. Bank, 152 Ill. App. 76, 78 (1909).

51 See Rightmire, Bad Faith in the Law of Negotiable Instruments (1920) 18 MITCE. L. REv. 355, 364.

52 Albert, Triphonoff, and Currie-MicGraw cases, supra note 49; State v. Langer, infra note 58. In Pingree Nat. Bank v. IfcFarland, 57 Utah 410, 418, 195 Pac. 313, 317 (1921) the court declined to decide whether "certain defenses may not be interposed against a postdated check which are not available against a check payable at the date of issue."

${ }^{63}$ Supra note 14.

54 The difference between regularity and notice is pointed out in Note (1922) 22 CoL. L. REv. 159, wherein the following brief test is announced: "Regularity depends on how desirable and frequent it is in business to postdate checks." It seems to be more accurate to say that regularity depends on how desirable and frequent it is to transfer yostdated checlis and malie them serve as a medium of exchange.

55 In Wilson v. Mid-West State Bank, 193 Iowa 311, 314, 186 N. W. 891, 893 (1922) Judge Weaver remarked, "Moreover, the checl in this instance was postdated by a matter of about three weeks, and therefore irregular and unauthorized, and not in due course of business. It carries the notice of its defect upon its face, and he who takes it holds it subject to that objection." The check in question had been certified, and so would be brought within the rules mentioned supra note 1 , but the case went further than that. The drawer, having sued her bank to prevent payment of the certified check and debit to her account, was allowed to prevail over the holder who intervened and made claim of being an innocent purchaser. The court was evidently satisfied that the intervener failed to prove himself a purchaser in good faith. 
by the writer, however, over several years and over a wide area has brought from bankers, merchants, and business men the assertion most often that postdated checks are irregular-although that view is by no means unanimous.

Perhaps a better test of regularity than what commercial men say about such paper is what they do with it. It is here that the results of a recent investigation may prove of value. No reliable way exists of finding out how many postdated checks are written or what per cent they are of all checks, but they are evidently a good many in the aggregate although only a small percentage of the whole.56 A record of the number deposited with any bank or presented to the drawee for payment would reveal little, since those items would be the ones which slipped through by oversight and the great bulk would evidently be held and put through when they are no longer postdated.57 A personal interview with officers of half a dozen banks in one large northern city disclosed none who would consider for an instant either discounting postdated instruments before their date or accepting them as collateral security to a loan, while one emphatically asserted that he would not even accept them for collection-doubtless an overstatement of the position of his institution. Scattering inquiries of bankers both north and south, in large places and small, disclosed an almost identical sentiment. And on top of this the banking superintendents and examiners in twenty states, ${ }^{\text {tg }}$ including those in which are situated most of the large commercial centers, knew of no such practice in their respective

56 "The practice of accepting postdated checks in this city is almost as common as the selling of merchandise." (Letter from firm of adjustors in New York City) But other letters suggest that in some communities at least the practice is far from common.

${ }^{57} \mathrm{~A}$ very large bank in Chicago made a five-day observation and reported thirteen postdated checks out of an approximate total of 160,000 checks presented for payment during that period. Similar observations for one week by a medium-sized bank, handling the business of smaller merchants in Cleveland, showed from four to thirteen postdated checks out of approximately 5,000 daily. The attitude of these banks was strongly to discourage the use of such checks, the larger bank stating that it would request tho termination of the account of a depositor who persisted in giving them.

58 California, Illinois, Indiana, Louisiana, Maryland, Massachusetts, Michigan, Minnesota, Missouri, Nebraska, New York, North Carolina, North Dakota, Ohio, Oregon, Pennsylvania, Tennessee, Texas, Virginia, Washington. The case of North Dakota is of particular interest becauso it is reported that some banks in that state during the Non-Partisan League regime had held postdated checks as security to loans. State v. Langer, 46 N. D. $462,488,177$ N. W. 408,419 (1919). The present state examiner, Hon. Gilbert Semingson, while, of course, accepting tho declaration of law in that decision to the effect that postdated checks aro negotiable and may be used as collateral security, states that the caso cited "had to do with an unusual situation. . . . The practice of carrying postdated checks as collateral has not been general at any time. . . Their use, if any, is negligible. None has come to our attention for many years." 
jurisdictions and all but three condemned it with varying degrees of warmth.

So much for the banking world. Among merchants a less unified front is presented but the problem is different with them. There is usually the sales element in their case, and a desire to move goods at a profit may cause them to take known and unknown risks. Furthermore, the problem may be presented to them in either of two ways. They may be asked to take the purchaser's own postdated check or, far less often, to take by indorsement from him the like instrument of another person. The first situation does not raise our problem, as there is no transfer which might amount to a negotiation and there is nothing usually involved but the credit of the drawer. The storekeeper when interviewed usually states as to the first of these situations that he would take without much hesitation the postdated check of a man in whom he had confidence and that on some occasions he had done so, understanding that he was to make no use of it until its date. Some cautious merchants state that they would refuse to take postdated checks from anyone, perhaps due to the notion existing in some quarters that they are illegal. In the second situation the tradesman states that he might (they are seldom certain) take the postdated check of an unknown drawer from a known good endorser or the check of a known good drawer from a person of unknown financial standing. But on being asked if this last would be true in case the drawer were, say, Henry Ford, they usually think they would be suspicious and want to know why MIr. Ford postdated his check since it would not seem to be for the usual reason-want of present funds. Furthermore, these tradespeople, so far as can be learned, generally make no effort to sell or pledge such paper in advance of its date and they state that they know of no market for it generally or any place where they could discount or borrow on it.

Collection agencies for obvious reasons seem to receive more postdated checks than any other business group, though some do not encourage the giving of them. Inquiries were made of seventy such concerns selected at random from the membership of the Commercial Law League of America in fifty-five cities and towns from coast to coast, including two in Canada, as to the practice in respect of such paper and whether they ever sold or discounted it or used it as collateral to loans. Sixty-eight replied indicating a negative answer to the question, most of them adding that they knew of no dealers or dealing in postdated checks either in their community or elsewhere. One southern writer saw no reason why the payee might not discount them if he wanted to and could find a buyer, and one letter from an important northern city suggested that "quite a business might 
be worked up handling postdated checks if it were properly advertised"; but most opinions were decidedly to the contrary. The practice seems to be that such checks are held in a suspension file until the date fixed by the drawer (or according to the system of some concerns, until just long enough before then to assure their arrival at the drawee's counter on that date).

Finally inquiries were directed to a selected list of companies, whose business included the financing of accounts receivable for merchants, to learn if they either discounted or loaned against postdated checks held by their customers or if not, whether they knew of any such practice. Illuminating replies on the matters in hand were received from eight companies located in the following cities: Los Angeles, Chicago, Indianapolis, New York, Philadelphia, and Baltimore. Seven declared that they never dealt in postdated paper and knew of no organization which did; also that they would not consider it good business to do so. The other company likewise reported that such financing arrangements were not customary in their field and that they did not make a practice themselves of discounting postdated checks or taking them as collateral, but that "in special cases," apparently rare, they had done so.

The isolated acts of one concern are not sufficient basis for any general rules favorable to the free circulation of postdated checks. Such transactions can, it seems, be adequately handled by reliance on the transferror or on the collateral pledged.

Returning to the legal phases of the matter in the United States, ${ }^{50}$ there can be no question but that the American courts following English authority have adjudged postdated checks to be negotiable from the time of issue. The decisions are also agreed that the date on the paper is not notice of defenses. And while the question of regularity seems never to have received any serious attention in this country, the result of the cases are consistent only with the rule that postdated checks are complete and regular.

But the British cases were entangled with questions of stamps, and their analysis was inadequate. The language of the Negotiable Instruments Law does not compel a holding that a postdated check is negotiable at the date of issue; indeed there is an

${ }^{50}$ Cases decided under bad check laws have relatively little bearing on the present problem when they hold as do the majority that postdated checks are not within the condemnation of the acts. Smith v. State, 147 Ark. 49, 226 S. W. 531 (1921). But it should not be overlooked that thoso cases which treat such paper as within the reach of the penal strtutes practically prevent the use of postdated checks as credit instruments. Pcople v. Bercovitz, 163 Cal. 636, 126 Pac. 479 (1912); Commonwealth v. Woolis, 15 Del. Co. Rep. 549 (Pa. Quar. Sess. 1921); State v. Avery, 111 Kan. 588, 207 Pac. 838 (1922) ; People v. Westerdahl, 316 Ill. 86, 146 N. E. 737 (1925). 
argument for a contrary interpretation. Other instruments in good commercial standing, as, e.g., bills or notes payable at the drawer's bank, ${ }^{, 0}$ supply all the features of the postdated' check as a credit instrument. Finally and most of all, the business world does not currently transfer and "negotiate" postdated checks in due course. Why then should postdated checks be legally classified as negotiable? Or if the weight of precedent seems too heavy on that point, why should they be classified as regular? ${ }^{61}$

Probably no one would think it desirable to have rules of business law radically different from what the business community would expect them to be. Commercial paper came to be recognized not because judges decided that money contracts should be of three classes, simple contracts, bonds, and negotiable instruments, but because the commercial world utilized bills and notes as money and ran its transactions on that basis; so it was that the ideas and expectations of merchants were of weight even after "the custom of merchants" had become "the law merchant" of the courts. Accordingly it is believed that any study of the law of postdated checks should be conducted in the light of what the business world thinks about such paper and, still more important, what it does with it. This article undertakes a start in that direction.

\footnotetext{
${ }^{60}$ Negotiable INSTRUMents Lat7 \$ 87 . A commercial banking firm in Baltimore stated its position as follows: "In our estimation it is not good business to discount postdated checks. In the event a merchant should be in need of money, we would much prefer to discount his note or his customer's notes and trade acceptances."

61 The conclusion in Comment (1920) 29 YALE L. J. 321, 325, "that postdated checks should find fuller recognition and come to fill their particular place of usefulness among the different types of commercial paper" is believed to be erroneous in so far as it commends them as credit instruments before their date.
} 